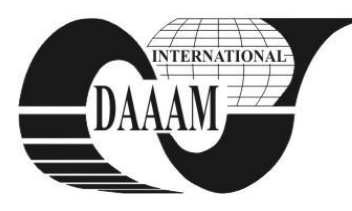

Annals of DAAAM for 2011 \& Proceedings of the 22nd International DAAAM Symposium, Volume 22, No. 1, ISSN 1726-9679 ISBN 978-3-901509-83-4, Editor B. Katalinic, Published by DAAAM International, Vienna, Austria, EU, 2011 Make Harmony between Technology and Nature, and Your Mind will Fly Free as a Bird Annals \& Proceedings of DAAAM International 2011

\title{
ENHANCEMENT OF STAGE-GATE PROCESS BY VALUE ANALYSIS
}

\author{
BROUM, T[omas]; KOPECKY, M[artin] \& KLEINOVA, J[ana]
}

\begin{abstract}
Innovation and development of new products are very current topics. General information about innovations is given at the beginning of paper. The stage - gate process which is one of the models for developing new products is described in the second chapter. Then value analysis is described. The value analysis is an important methodological tool for initiating innovations of existing or proposed technical products. Comparison of the approaches is in chapter four. The aim of the paper is given in the fifth chapter. The aim of this paper is to describe a way of reducing the costs of innovation. This was done by the application of value analysis to the stage - gate process.
\end{abstract}

Key words: innovation, stage-gate process, value analysis, product, process

\section{INTRODUCTION}

Innovations and new product development are very current topics. Innovations are important for the success of every company. If our company does not make any innovations, other companies will. Life cycles of technical products are getting shorter. New products have to be launched on to the market very often. The approach of "pressure of development" is changing to "pull of development". (Vacek 2008)

Products which companies launch on the market have to be competitive and have to find a way to the customers or customers have to find a way to them. They can be new products or improved existing products, which can offer the customer higher quality for the same price. Innovations do not apply only to products. The issue of innovations extends to other areas like technology, production processes, organization, strategy, marketing etc.

The issues of innovations are very difficult. Current difficulties of innovations are:

- more than $80 \%$ of innovations are unsuccessful before delivery to market

- more than $80 \%$ of innovations are unsuccesful after delivery to market

- more than $90 \%$ of innovations are delivered late to market, they are expensive and are low quality

- approximately $97 \%$ of innovation related patents are unprofitable

- analysis of 3 million innovations showed that key innovations depend on:

- resolution of contradiction (for example-increase rigidity and decrease weight at the same time) approximately $85 \%$ of cases

- addition of new function, attribute or property approximately $15 \%$ of cases

Successful innovation is not possible without a strong connection with the market and customers. We have to know our important business processes. We have to respect questions like: where is the market? , when will there be a new market? who is the customer? etc. We have to compare these questions with the following possibilities: what are we able to create? How do we create user friendly products? Which construction and technology is the best for lower cost?, and many more factors.

There are a lot of approaches, methods and tools available which concentrate on the issue of how to create a product which will be innovative and successful on the market. One of the best methods for improving the current situation concerning innovations is the stage-gate process. Innovations can cause an unacceptable increasing in costs compared to the value that they bring to the customer. The aim of this paper is to find a way of reducing the costs of innovation. We can improve the current situation by implementing the Value Analysis into stage-gate model. This can also reduce costs of innovated product to acceptable level.

\section{STAGE - GATE PROCESS}

The stage-gate process is one of the best known methods for the process of developing new products. The stage-gate process was created by Robert G. Cooper. The first version of this method was applied by NASA in the 1960s. This method was applied partially or completely in many companies in the USA and Europe. The stage-gate process model is used all around the world today. This method is used in the following companies: Hewlett Packard, IBM, Kodak, Microsoft, Procter\&Gamble, Polaroid, Lego, Carlsberg, Shell, Visa, Royal Bank of Canada and many others. This method is based on experiences, knowledge, references, observation of the approaches of management and results of research. (Cooper 2001).

The aims of this method are: (Vacek 2008):

- stop bad projects

- differentation of good and bad projects

- better product portfolio

The classic model of stage-gate is shown in Fig.1. We can find this model in literature in other forms (these forms are simpler). This article focuses only on the classic model. (Cooper 2001)

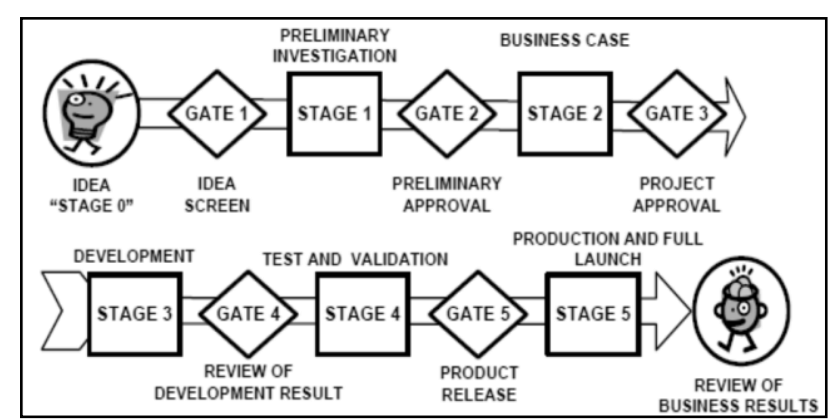

Fig. 1 Classic model of stage - gate process 
The whole process is separated into stages and gates. Stages are defined by inputs and outputs. These inputs and outputs are exactly described. We evaluate the outputs from every stage in the next gate. We have to decide to either continue or stop the project at the gates. An integrated team makes this decision in accordance with established rules. We eliminate the worst projects using this approach and we improve the products portfolio. There is more information about the stage-gate process in (Cooper 2001) and in other publications by Professor Cooper.

\section{VALUE ANALYSIS}

Value analysis is a methodological tool for initiating innovations of existing or proposed technical products. The initiation of innovation is based on functional-cost analysis of the product in value analysis methodology.

Value analysis can be defined as an organized and creative approach that aims to identify unnecessary costs and leads to their elimination. The unnecessary costs are costs that do not increase the quality or other properties of the product desired by the customer. Value analysis centres aspects of design, production and use to a single goal - preserving desired functions and other required properties of the product while reducing costs. (Miles, 1971), (Eder et al., 2010)

Value analysis uses a set of special methods, gained knowledge and experience to achieve its aim.

Value analysis is based on the answers to five questions described by (Miles, 1971):

- What is the item or service?

- What does it cost?

- What does it do?

- What else would do the job?

- What would that alternative cost?

The questions mentioned above are important for the job plan of Value analysis. The job plan is based on these questions.

The job plan is used to control the work on value analysis. The steps of the job plan follow (Miles, 1971):

Orientation - Information - Creative thinking - Analysis Planning - Realization - Summary

\section{COMPARISON OF APPROACHES}

The job plan of the value analysis and the stages of the stage - gate process are compared in Table 1. The aim of the comparison was to find the intersection of these approaches to integrate the value analysis into the model of the stage - gate process. It can lead to reduction of innovation costs which could potentially increase the competitiveness of the innovated product.

\begin{tabular}{|l|l|l|}
\hline $\begin{array}{l}\text { Steps of value } \\
\text { analysis }\end{array}$ & Stages in stage-gate process & $\begin{array}{l}\text { Intersections } \\
\text { of VA in SG }\end{array}$ \\
\hline 1-Orientation & 1-Preliminary investigation & 1,2 \\
\hline 2-Information & 2-Business case & 2 \\
\hline $\begin{array}{l}\text { 3-Creative } \\
\text { thinking }\end{array}$ & 3-Development & $3,4,5,6,7$ \\
\hline 4-Analysis & 4-Test and validation & \\
\hline 5-Planning & $\begin{array}{l}\text { 5-Production and full } \\
\text { launch }\end{array}$ & \\
\hline 6-Realization & & \\
\hline 7-Summary & & \\
\hline
\end{tabular}

Tab. 1. Comparison of approaches

It is important to mention that in the stage of test and validation in the stage - gate process the results of testing the prototype are obtained. This often leads to the discovery of problems related to the product. It is the reason why the value stage should be added after the testing and validation stage in the stage - gate process. This is the last chance to modify the product value before placing it on the market, so it is the reason why it should be used. The value stage should aim to remove the problems related to the value of the product. It should increase the value of the product for the customer.

\section{RESULTS - NEW APPLICATIONS}

The modified model of the stage - gate process is obtained by applying value analysis to the model of the stage - gate process. The modified model is shown in Fig 2. Stages 1,2 and 3 are modified. Corresponding value activities run in parallel to the modified stages. Another modification is the addition of the value stage. This stage answers the five basic questions of value analysis. The value stage is placed after stage $4-$ test and validation. The new modified model should increase the value of innovation by appropriate integration of value analysis into the original stage - gate process.

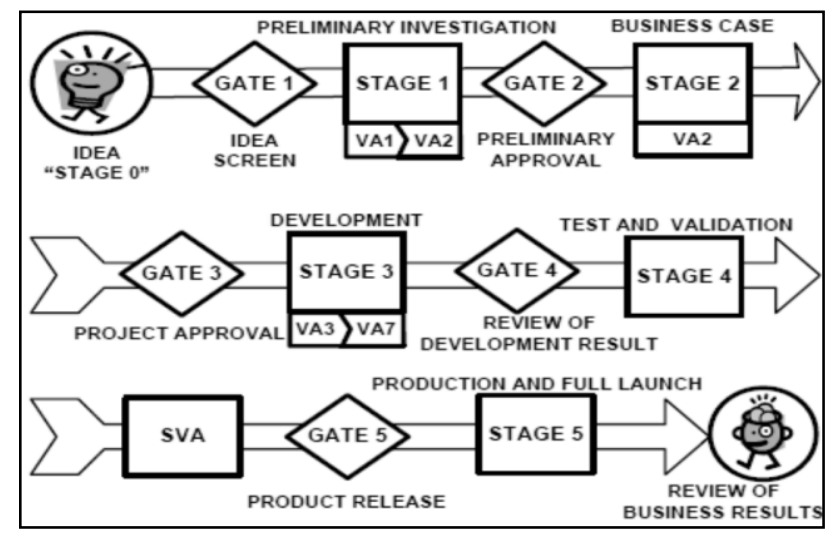

Fig. 2. Modified model of stage - gate process

\section{CONCLUSION}

This paper deals with two known methods, value analysis and the stage-gate process. The paper focuses on the issue of the development process of new (innovated) products, because products can be too expensive after placing on the market which can lead to products losing their competitiveness. The modified model of the stage-gate process is obtained by combining these two approaches. Application of the modified model of the stage-gate process can reduce the costs of innovation to a minimum level and it can enhance the competitiveness of the innovated product. The modified model can be used generally for issues concerning innovations of products.

\section{ACKNOWLEDGEMENTS}

This paper includes results from Project No. 402/08/H051 Optimizing multidisciplinary designing and modelling production systems subsidised by the Grant Agency of the Czech Republic.

\section{REFERENCES}

Cooper, G. R. (2001). Winning at New Products: Accelerating the process from idea to launch - third Edition, Basic Books, ISBN 978-0-7382-0463-5, New York, USA

Eder, W. E.; Hosnedl, S. (2010). Introduction to Design Engineering: Systematic Creativity and Management. CRC Press / Balkema, Taylor \& Francis Group, Leiden, The Netherlands, 456 pp., ISBN: 978-0-415-55557-9

Miles, L.D.(1971). Hodnotová analyza, ALFA n.p., ISBN 63-045-71, Bratislava,Czechoslovakia

Šimon, M. \& Troblová, P. (2007). Effective design aspects of production systems, In: Annals of DAAAM for 2007, str.691-692, ISBN 3-901509-58-5, Zadar, Croatia

Vacek, J. (2008). Strukturování a hodnocení inovačních procesů [Inaugural dissertation], Plzeň, pg. 86. Západočeská Univerzita v Plzni. Fakulta strojní 